\title{
Keterbukaan Informasi Sebagai Mitigasi Risiko Peer To Peer Lending (Perbandingan Antara Indonesia Dan Amerika Serikat)
}

\author{
Inda Rahadiyan dan Nikmah Mentari \\ Fakultas Hukum Universitas Islam Indonesia Yogyakarta Indonesia \\ Fakultas Hukum, Universitas Hang Tuah Surabaya Jawa Timur Indonesia \\ Jln. Tamansiswa No. 158 Yogyakarta Indonesia \\ Jln. Arif Rahman Hakim, No. 150 Surabaya Jawa Timur Indonesia \\ indarahadiyan1@gmail.com; 2nikmah.mentari@hangtuah.ac.id
}

Received: 2 Desember 2020; Accepted: 25 April 2021 Published: 2 Juni 2021

DOI: 10.20885/iustum.vol28.iss2.art5

\begin{abstract}
The development of peer to peer lending (P2PL) in Indonesia will always be followed by the formation of the latest regulations. However, the existing regulations do not sufficiently regulate the disclosure of information. On the other hand, in the United States as the country with the largest P2PL, information disclosure is a major part in the implementation of P2PL. The approaches used in this research are a conceptual approach, a statutory approach, and a comparative law approach. The results conclude that obtained are that the regulation regarding P2PL does have an obligation to disclose information, but the regulation is not comprehensive because it is exclusive and limited. In fact, the disclosure of information can be a part of risk mitigation in P2PL, for example, minimizing the risk of problem loans. Meanwhile, in the United States, through the Security Exchange Commission (SEC) and the Consumer Financial Protection Bureau (CFPB), detailed and periodic information disclosure is available. So that both prospective borrowers and potential lenders can consider the risks and capabilities of each party more before making transactions in P2PL. This then can be one of the risk mitigation for P2PL in the United States.
\end{abstract}

Key Words: Indonesia; information disclosure; P2PL; risk mitigation; United States

\section{Abstrak}

Perkembangan peer to peer lending (P2PL) di Indonesia akan selalu diikuti oleh pembentukan regulasiregulasi terbaru. Akan tetapi, peraturan yang telah tersedia belum cukup mengatur mengenai keterbukaan informasi. Sebaliknya, di Amerika Serikat sebagai negara dengan P2PL terbesar, keterbukaan informasi sebagai bagian utama dalam penyelenggaraan P2PL. Pendekatan yang digunakan dalam penelitian ini adalah pendekatan konseptual, pendekatan perundang-undangan, serta pendekatan perbandingan hukum. Hasil yang diperoleh menyimpulkan yakni peraturan mengenai P2PL memang telah memiliki kewajiban keterbukaan informasi, akan tetapi peraturan tersebut kurang komprehensif karena bersifat eksklusif dan terbatas. Padahal keterbukaan informasi tersebut dapat menjadi bagian dari mitigasi risiko dalam P2PL, misalnya meminimalisir risiko pinjaman bermasalah. Sedangkan, di Amerika Serikat, melalui Security Exchange Commission (SEC) dan Consumer Financial Protection Bureau (CFPB), keterbukaan informasi tersedia secara detail dan berkala. Sehingga baik para calon peminjam maupun calon pemberi pinjaman dapat lebih mempertimbangkan risiko-risiko maupun kemampuan masing-masing pihak sebelum melakukan transaksi di P2PL. Hal ini kemudian dapat menjadi salah satu mitigasi risiko bagi P2PL di Amerika Serikatt.

Kata-kata Kunci : Amerika Serikat, Indonesia, keterbukaan informasi; mitigasi risiko, P2PL 


\section{Pendahuluan}

Perkembangan teknologi informasi secara fundamental mengubah banyak model bisnis tradisional. Munculnya internet dan akibat peluang yang difasilitasi untuk kegiatan kewirausahaan, telah melahirkan sejumlah besar bisnis nontradisional dan model bisnis baru yang mencakup apa yang disebut "Ekonomi Berbagi" (sharing economy). Model bisnis Ekonomi Berbagi biasanya berbasis platform untuk menyesuaikan permintaan dan penawaran. Meningkatnya penggunaan internet dan kemungkinannya, memungkinkan platform online yang mudah dan murah untuk diakses. ${ }^{1}$ Oleh karena itu, terdapat korelasi erat antara teknologi, bisnis dan internet dalam berbagai industri, termasuk industri keuangan (financial industry).

Sektor jasa keuangan sedang dalam tahap awal disrupsi digital. Fungsi utamanya saat ini sama seperti kemarin - orang menggunakan layanan keuangan untuk menukar uang, menabung atau berinvestasi, membiayai, atau mengasuransikan risiko. Semua layanan keuangan merupakan respon terhadap empat kebutuhan dasar ini, dan ini tidak akan berubah. Namun, yang berubah adalah cara kebutuhan ini ditangani. ${ }^{2}$

Teknologi yang berkaitan dengan industri keuangan yang saat ini sedang populer yakni financial technology. Financial technology (fintech) adalah penggunaan teknologi sebagai cara untuk mengatasi permasalahan keuangan. ${ }^{3}$ Menurut Roy S. Freedman, financial technology is concerned with building systems that model, value, and process financial products such as bonds, stocks, contracts, and money.4 Sehingga, dapat disimpulkan bahwa fintech merupakan produk keuangan yang berfokus pada sistem yang terorganisasi, nilai dan proses produk keuanngan seperti obligasi, saham, dan lainnya.

Berbagai jenis layanan fintech masuk ke dalam bidang jasa yang meliputi; pembayaran dan transfer, pinjaman dan pembiayaan, bank retail, manajemen

\footnotetext{
${ }^{1}$ Tran Dinh Uyen and Hoang Ha, "The Sharing Economy and Collaborative Finance: the Case of P2P Lending in Vietnam", Jurnal Ekonomi Bisnis, Vol. 22, No.2, Agustus 2017, hlm. 84.

2 Susanne Chisthi and Janos Barberis, The Fintech Book: The Financial Technology Handbook for Investors, Enterpreuners and Visionaries, John Wiley \& Sons Ltd, West Sussex, 2016, hlm. 226. Baca pula: Agustin Rubini, Fintech in A Flash: Financial Technology Made Easy, Simtac Ltd, London, 2017, hlm. 15.

3 Arner, D.W., Barberis, J., and Buckley, R.P. The Evolution of FinTech: A New Post-Crises Paradigm?, 2015, University of Hongkong, hlm. 32 .

${ }^{4}$ Roy S. Freedman, Introduction to Financial Technology, Complete Technology Guides for Financial Services, Elsevier, California, 2006, hlm. 1
} 
keuangan serta jual-beli mata uang. ${ }^{5}$ Beberapa faktor yang mendorong fintech berkembang di Indonesia: ${ }^{2}$

Pertama, fintech didorong oleh perilaku konsumen. Fintech memberikan kenyamanan bagi konsumen karena dapat diakses dengan mudah, kapan saja dan di mana saja. Mode layanan pada fintech sangat berbeda dari bank konvensional seperti biaya yang lebih rendah dan batasan yang lebih sedikit. Pemerintah mendorong layanan keuangan berkembang sehingga dapat menjangkau segmen yang kurang terlayani dan memberikan biaya transaksi yang lebih rendah kepada nasabah. Pinjaman bank sulit didapat sehingga hal ini dapat mempengaruhi usaha kecil dan menengah dalam memanfaatkan layanan perbankan tertentu.

Kedua, fintech akan mengubah masyarakat dari berbasis uang tunai menjadi masyarakat tanpa uang tunai (cash to cashless). Sebelum adanya fintech, hampir setiap transaksi di Indonesia dilakukan dengan uang tunai. Saat ini, dengan munculnya startup fintech, orang lebih menyukai transaksi tanpa uang tunai. Penyedia gateway pembayaran seperti GoPay, GrabPay, DOKU, Midtrans, dan Xendit dengan ratusan inovasi fintech lainnya telah meningkat.

Ketiga, Indonesia dikatakan sebagai negara dengan penduduk tanpa rekening bank (unbanked people) tertinggi di dunia. Lebih dari 50 juta UMKM di Indonesia, hanya $12 \%$ yang memiliki akses kredit karena kurangnya riwayat kredit, laporan, atau jaminan. Menariknya, UMKM tersebut memberikan lebih dari setengah persentase dari total PDB di Indonesia.

Asosiasi Fintech Indonesia melaporkan bahwa perusahaan Fintech di Indonesia masih didominasi oleh perusahaan pembayaran (44\%), agregator $(15 \%)$, pembiayaan $(15 \%)$, perencana keuangan untuk personal maupun perusahaan $(10 \%)$, crowdfunding $(8 \%)$ dan lainnya $(8 \%)$. Sedangkan, platform Fintech yang saat ini mendapatkan perhatian besar ialah P2P Lending (P2PL) dan Payment gateway. ${ }^{7}$ Pada tahun 2017 jenis fintech yang mendominasi di Indonesia ialah Peer to Peer Lending (P2PL) yang mengalami pertumbuhan pelaku usaha P2PL sebesar $32 \%$ dari 2016 hanya berkisar 16\%. ${ }^{8}$

\footnotetext{
${ }^{5}$ Baca: Kevin David, et.all, "Catching-Up with Indonesia’s Fintech Industry”, Working Paper, Australian Centre for Financial Studies Monash Univesity, May 2017, https://australiancentre.com.au/wpcontent/uploads/2017/05/2 Catching-Up-with-Indonesias-Fintech-Industry.pdf, diakses 30 Nopember 2019.

6 Muhammad Anshari, Mohammad Nabil Almunawar dan Masairol Masri, An Overview of Financial Technology in Indonesia, Chapter 12, An Overview of Financial Technology in Indonesia, IGI Global, 2020, hlm. 219.

7 Yuliyanti M. Manan, "Sistem Integrasi Proteksi \& Manajemen Resiko Platform Fintech peer to Peer (P2P) Lending dan Payment Gateway untuk Meningkatkan Akselerasi Pertumbuhan UMKM 3.0," Journal of Islamic Economic, Finance, and Banking, Vol.2, No.1, Juni 2019, hlm. 75.

8 CNBCIndonesia, "Ini dia empat jenis fintech di Indonesia", https://www.cnbcindonesia.com/tech/20180110145800-37-1126/ini-dia-empat-jenis-fintech-di-indonesia diakses 28 Oktober 2019; lihat Kieran Garvey. Et.all., "Laporan Industri Keuangan Alternatif Asia-Pasifik Ke-2: Meningkatkan Pertumbuhan", The Australian Centre for Financial Studies Monash University bekerja sama dengan
} 
Peer-to-Peer Lending dapat didefinisikan sebagai "pertukaran keuangan" yang terjadi secara langsung antara individu, tanpa perantara langsung dari lembaga keuangan tradisional. Bank masih berperan, seperti yang diberikan oleh peraturan, mereka bertindak sebagai lembaga penyimpanan, digunakan untuk menyediakan platform dengan akun tempat uang disimpan, dan menaruhnya di pembuangan platform. ${ }^{9}$ Terminologi 'peer-to peer' dapat dikatakan paling tepat untuk pinjaman berskala kecil dari pemberi pinjaman perorangan kepada peminjam perorangan yang mungkin hendak mencari dana untuk pembelian konsumen atau kebutuhan konsumtif. ${ }^{10}$

Platform P2PL menyediakan pasar online yang sesuai dengan investor yang akan memberi pinjaman pada calon peminjam, sehingga menghapus kebutuhan bank yang biasanya bertindak sebagai perantara (intermediary). ${ }^{11}$ Pemberi pinjaman mungkin individu atau badan usaha, tergantung platform. Secara tradisional, bank umumnya enggan memberi pinjaman kepada perusahan yang lebih kecil karena tingkat gagal bayar yang lebih tinggi, kurangnya data dan skala kecil membuat pinjaman dirasa kurang menguntungkan. ${ }^{12}$

Oleh karena itu, perkembangan fintech khususnya jenis Peer to Peer Lending (P2PL) yang sangat pesat di Indonesia kemudian diikuti dengan upaya pengaturan oleh Bank Indonesia dan Otoritas Jasa Keuangan (OJK) selaku regulator dan pengawas. ${ }^{13}$ Peraturan dari Bank Indonesia maupun OJK ialah sebagai berikut:

1. Peraturan Bank Indonesia Nomor 19/12/PBI/2017 tentang Penyelenggaraan Teknologi Finansial (PBI 19/12/2017);

2. Peraturan Otoritas Jasa Keuangan Nomor 77/POJK.01/2016 tentang Pinjam Meminjam Uang Berbasis Teknologi Informasi (POJK 77/2016);

Cambridge Centre for Alternative Finance dan Tsinghua University, https://australiancentre.com.au/wpcontent/uploads/2017/09/APAC BH e.pdf, diakses 25 Nopember 2018.

9 Eugenia Omarini A, "Peer-to-peer Lending: Business Model Analysis and the Platform Dilemma," International Journal of Finance, Economics and Trade (IJFET), 2(3), 2018, hlm. 31. Baca pula: Mark Cummins, et.al, Addressing Information Asymmetries in Online Peer-to-Peer Lending, dalam Theo Lynn, et.al, Disrupting Finance: Fintech and Strategy in $21^{\text {st }}$ Century, Springer Nature, Switzerland, 2019, hlm. 16-17.

${ }^{10}$ Lihat catatan kaki pada Naoko Nemoto dan Bihong Huang, "Optimal Regulation of P2P Lending for Small and Medium-Sized Enterprises”, ADBI Working Paper Series, No. 912, January 2019, hlm. 1

${ }^{11}$ Ibid

12 Ibid.

13 Inda Rahadiyan dan M. Hawin, "Pengaturan dan Penerapan Mitigasi Risiko Dalam Penyelenggaraan Peer to Peer Lending Guna Mencegah Pinjaman Bermasalah”, Jurnal Hukum, IUS QULA IUSTUM, No.2, Vol.27, Mei 2020, hlm. 288. 
3. Peraturan Otoritas Jasa Keuangan Nomor 18/POJK.03/2017 tentang Pelaporan dan Permintaan Informasi Debitur Melalui Sistem Layanan Informasi Keuangan (POJK 18/2017)

4. Peraturan Otoritas Jasa Keuangan Nomor 13/POJK.02/2018 tentang Inovasi Keuangan Digital di Sektor Jasa Keuangan (POJK 13/2018). ${ }^{14}$

Berdasarkan POJK 77/2016, layanan pinjam meminjam uang berbasis teknologi informasi adalah penyelenggaraan layanan jasa keuangan untuk mempertemukan pemberi pinjaman dengan penerima pinjaman dalam rangka melakukan perjanjian pinjam meminjam dalam mata uang Rupiah secara langsung melalui sistem elektronik dengan menggunakan jaringan internet. ${ }^{15}$

Penelitian sebelumnya yang telah dilakukan oleh Inda Rahadiyan dan M. Hawin (2019), tentang pengaturan dan penerapan mitigasi risiko dalam penyelenggaraan peer to peer lending guna mencegah pinjaman bermasalah, menyimpulkan bahwa di Indonesia saat ini belum ada pengaturan mengenai ambang batas maksimum Non Performance Loan (NPL). ${ }^{16}$ Hal itu menimbulkan lemahnya kepastian serta perlindungan hukum. Penyebabnya ialah aturan yang masih tersebar di beberapa peraturan, baik OJK maupun PBI. Pada sisi penerapan mitigasi risiko pinjaman macet dilakukan melalui pemantauan mandiri oleh penyelenggara. Selain itu, beberapa perusahaan P2PL menerapkan mitigasi risiko secara internal dalam rangka memitigasi risiko pinjaman bermasalah yang berpotensi menjadi pinjaman macet. ${ }^{17}$

Selain belum diaturnya perihal mitigasi risiko pinjaman bermasalah secara jelas dan terperinci, persoalan lain yang muncul berkaitan dengan penyaluran

${ }^{14}$ Hendrikus Passagi, "Fintech Lending Indonesia Pendanaan Gotong Royong Online", Materi Seminar Nasional "Implementasi dan Tantangan Fintech Lending di Indonesia", Kerjasama antara Business Law Community Fakultas Hukum UGM dengan Otoritas Jasa Keuangan Republik Indonesia, Yogyakarta, Fakultas Hukum UGM, 22 September 2018.

15 Pasal 1 angka 3 POJK Nomor 77/POJK.01/ 2016 Tentang Layanan Pinjam Meminjam Uang Berbasis Teknologi Informasi

${ }^{16}$ Non performing loan (NPL) adalah salah satu indikator kunci untuk menilai kinerja fungsi bank, karena NPL yang tinggi adalah indikator gagalnya bank dalam mengelola bisnis antara lain timbul masalah likuiditas (ketidakmampuan membayar pihak ketiga), rentabilitas (hutang tidak dapat ditagih), dan solvabilitas (modal berkurang). Penjelasan dapat dilihat pada Deasy Dwihandayani, “Analisis Kinerja Non Performing Loan (NPL) Perbankan di Indonesia dan Faktor-Faktor yang Mempengaruhi NPL", Jurnal Ekonomi Bisnis, Vol.22, No.3, Desember 2017, hlm, 266; lihat pula Anin Diyanti dan Endang Tri Wiyarti, "Analisis Pengaruh Faktor Internal dan Eksternal Terhadap Terjadinya Non Performing Loan (Studi Kasus pada Bank Umum Konvensional yang Menyediakan Layanan Kredit Pemilikan Rumah Periode 2008-2011)", Diponegoro Journal of Management, Vol.1, No.2, 2012. Secara umum NPL berkaitan dengan kredit bermasalah.

17 Inda Rahadiyan dan M. Hawin, Op. Cit., hlm. 303. 
dana melalui mekanisme P2PL adalah mengenai belum adanya aturan yang jelas dan tegas terhadap mekanisme penilaian kelayakan calon debitor. ${ }^{18}$ Hal demikian juga dapat menimbulkan persoalan tersendiri mengingat seluruh proses penilaian kelayakan calon debitor dilakukan secara mandiri oleh pihak penyelenggara. Sementara itu, keputusan pemberian pinjaman oleh pihak kreditor dilakukan dengan mendasarkan pada hasil penilaian kelayakan calon debitor oleh pihak penyelenggara. Hal demikian juga disebabkan oleh minimnya informasi yang tersedia serta informasi mengenai risiko-risiko yang mungkin terjadi bagi calon lender maupun calon borrower.

Pembicaraan mengenai pengaturan mitigasi risiko dimaksud, tentu tidak dapat dilepaskan dari praktek pengaturan yang diterapkan di negara lain. Negara dengan pangsa pasar Peer to Peer Lending terbesar di dunia adalah Amerika Serikat. Berdasarkan laporan Global Perspective 2013, jumlah total pendanaan P2PL mencapai angka 6.400.000.000.000 USD. Jumlah tersebut terbagi ke dalam pangsa pasar Amerika Serikat sebesar 51\%, China sebesar 28\% dan United Kingdom sebesar $17 \%{ }^{19}$

Penyelenggaraan P2PL di Amerika Serikat pada mulanya juga mengalami masalah, namun negara tersebut terus memperbaiki regulasi khususnya pada aspek keterbukaan informasi sebagai salah satu mitigasi risiko. Keterbukaan informasi dimaksud yakni dilakukan melalui penyusunan pedoman umum (guidance). Kondisi demikian menghasilkan keragaman bentuk implementasi mitigasi risiko oleh perusahaan penyelenggara. Implementasi mitigasi risiko oleh perusahaan penyelenggara bergantung pada model bisnis yang dijalankan oleh masing-masing penyelenggara. Setidaknya terdapat dua model bisnis P2PL yang dikenal di dalam praktik di Amerika Serikat. Kedua model bisnis tersebut adalah Notary Model dan Client Segregated Account Model. ${ }^{20}$

\footnotetext{
${ }^{18}$ Sarwin Kiko Napitupulu, et.all., "Kajian Perlindungan Konsumen Sektor Jasa Keuangan: Perlindungan Konsumen Pada Fintech", Departemen Perlindungan Konsumen Otoritas Jasa Keuangan Republik Indonesia, 2017, hlm.32

${ }^{19}$ Benjamin Kafer, "Peer to Peer Lending: A Financial Stability Risk Perspective", hlm. 3 diakses dari http://www.uni-marburg.de/fb02/makroforschung/magkspapers diakses 16 Juli 2019.

${ }^{20}$ Ibid., hlm. 4. Under the prevailing business model in the US, the notary model, the platform matches borrowers and lenders and transfers the loan amount to a partner bank. This bank originated as traditional consumer loan to the borrower, sells a note to the platform, and the platform sells this note to the lender. The borrowers' repayments are then collected by the platform and returned to lenders. Under the client segregated account model, no bank is required and loan contracts are directly set up between borrow ers and lenders. As a result, this setup leaves less room for the inclusion of and dependency on the platform.
} 
Penelitian ini akan mengkaji lebih mendalam pentingnya keterbukaan informasi sebagai mitigasi risiko terhadap peer to peer lending (P2PL). Hal ini mengingat keterbukaan informasi pada pengaturan P2PL di Indonesia masih sangat terbatas. Padahal, di negara Amerika Serikat keterbukaan informasi menjadi salah satu faktor utama dalam mitigasi risiko pada industri P2PL.

\section{Rumusan Masalah}

Berdasarkan uraian sebagaimana tersebut di atas maka penelitian ini fokus mengkaji pada dua hal, yaitu sebagai berikut: pertama, bagaimana pengaturan keterbukaan informasi terhadap mitigasi risiko pada peer to peer lending (P2PL) di Indonesia? Kedua, bagaimana penerapan keterbukaan informasi sebagai mitigasi risiko peer to peer lending (P2PL) di Amerika Serikat?

\section{Tujuan Penelitian}

Penelitian ini bertujuan untuk menganalisis keterbukaan informasi terhadap mitigasi risiko P2PL di Indonesia, serta penerapan keterbukaan informasi di Amerika Serikat sebagai bahan rujukan pada mitigasi risiko P2PL di Indonesia.

\section{Metode Penelitian}

Penelitian dalam karya ini ialah penelitian hukum normatif. Pendekatan yang digunakan dalam penelitian ini adalah pendekatan konseptual (conceptual approach), pendekatan perundang-undangan (statute approach), serta pendekatan perbandingan (comparative approach). Pendekatan konseptual merupakan pendekatan yang beranjak dari pandangan-pandangan dan doktrin-doktrin yang berkembang dalam ilmu hukum. ${ }^{21}$ Pendekatan perundang-undangan (statue approach) yakni menelaah dan mengkaji keseluruhan undang-undang dan regulasi yang saling berkaitan dengan isu hukum yang sedang diteliti. ${ }^{22}$ Menurut Van Apelddorn, suatu perbandingan hukum sebagai ilmu bantu untuk ilmu hukum dogmatik. Oleh karena itu, untuk menimbang dan menilai aturan-aturan hukum dan putusan-putusan pengadilan yang ada dengan sistem hukum lain. ${ }^{23}$

${ }^{21}$ Abdulkadir Muhammad, Hukum dan Penelitian Hukum, 2004, Cetakan Kesatu, Bandung, PT Citra Aditya Bakti hlm. 135.

${ }^{22}$ Ibid., hlm. 133.

23 Peter Mahmud M, Penelitian Hukum, Kencana Prenada Media Group, Jakarta, 2013, hlm. 172. 
Pendekatan perbandingan hukum dengan menelaah persamaan dan perbandingan diantara beberapa negara. ${ }^{24}$ Dalam hal ini, negara yang menjadi perbandingan ialah Amerika Serikat.

Fokus penelitian adalah keterbukaan informasi sebagai mitigasi risiko peer to peer lending di Indonesia dan Amerika Serikat. Bahan hukum yang dianalisis yang terdiri dari bahan hukum primer, bahan hukum sekunder dan bahan hukum tersier. Keseluruhan bahan hukum dianalisis secara kualitatif sesuai dengan relevansinya terhadap permasalahan penelitian yang kemudian disajikan dalam bentuk narasi deskriptif eksploratif dan argumentatif.

\section{Hasil Penelitian dan Pembahasan}

Pengaturan Keterbukaan Informasi Terhadap Mitigasi Risiko Pada P2PL di Indonesia

Bagi pemberi pinjaman (lender), platform P2PL dianggap sebagai sebuah wadah untuk berinvestasi. Hal ini mengingat, adanya bunga yang diberikan sehingga dana yang disalurkan melalui P2PL akan memperoleh keuntungan. Pada pihak penerima pinjaman (borrower), platform P2PL sama halnya dengan industri perbankan, yakni memberikan pinjaman. Oleh karena itu, para pihak yang bersangkutan membutuhkan informasi yang jelas, tegas dan detail tanpa mengesampingkan perlindungan data pribadi.

Pengaturan tentang P2PL yang tertuang pada POJK 77/2016, memang memberikan kewajiban bagi pihak Penyelenggara untuk menyediakan dan memberi akses informasi kepada kedua belah pihak. Seperti tertuang pada Pasal 19 ayat (3) Penyelenggara wajib menyediakan akses informasi kepada Pemberi Pinjaman atas penggunaan dananya. Selanjutnya pada ayat (4) menyebutkan bahwa Akses informasi sebagaimana dimaksud pada ayat (3) tidak termasuk informasi terkait identitas Penerima Pinjaman. Kewajiban informasi sedikitnya memuat: 25

a. Jumlah dana yang dipinjamkan kepada Penerima Pinjaman;

b. Tujuan pemanfaatan dana oleh Penerima Pinjaman;

c. Besaran bunga pinjaman; dan

d. Jangka waktu pinjaman.

${ }^{24}$ Ibid., hlm. 176

25 Pasal 19 ayat (5) POJK 77/2016. 
Sedangkan kewajiban informasi kepada penerima pinjaman (borrower) yaitu tertuang pada Pasal 20 ayat (3) yang berbunyi "Penyelenggara wajib menyediakan akses informasi kepada Penerima Pinjaman atas posisi pinjaman yang diterima." Pada ayat (4), akses informasi sebagaimana dimaksud pada ayat (3) tidak termasuk informasi terkait identitas Pemberi Pinjaman.

Kewajiban informasi dalam POJK tersebut belum cukup meng-cover kebutuhan para pihak selaku pengguna platform P2PL. Hal ini mengingat P2PL tidak terlepas dari adanya risiko. Risiko kredit misalnya pada jasa P2PL, adalah risiko kegagalan penerima pinjaman untuk memenuhi kewajiban kepada pemberi pinjaman, yang mana peminjam telah gagal memenuhi kewajiban kepada pemberi pinjaman. ${ }^{26}$ Terkait dengan mitigasi risiko, POJK 77/2016 telah mengatur secara singkat pada BAB V Pasal 21 sampai dengan Pasal 24.

Pasal 21 mengatur tentang Penyelenggara dan Pengguna yang berkewajiban melakukan mitigasi risiko. Hal ini mengingat status Penyelenggara adalah pihak yang menyediakan, mengelola, dan mengoperasikan Layanan P2PL. Sedangkan, Pengguna adalah pemberi pinjaman dan penerima pinjaman yang mengunakan Layanan P2PL. Pihak-pihak tersebut merupakan subyek dalam sistem P2PL, sehingga seluruh risiko pun akan berdampak pada para subyeknya.

Adapun apabila hendak mengetahui terkait dengan kondisi debitur atau dalam hal ini borrower diatur dalam POJK Nomor 18/POJK.03/2017 tentang Pelaporan dan Permintaan Informasi Debitur Melalui Sistem Layanan Informasi Keuangan (POJK 18/2017). Pasal 1 Angka 10 POJK 18/2017 menjelaskan tentang Laporan Debitur ialah informasi yang disajikan oleh Pelapor kepada OJK menurut tata cara dan bentuk laporan serta media laporan yang ditetapkan oleh OJK.

Selanjutnya pada Pasal 1 Angka 12 yang dimaksud dengan informasi debitur ialah informasi mengenai debitur, fasilitas penyediaan dana yag diterima debitur, dan informasi terkait lain yang disajikan berdasarkan Laporan Debitur yang diterima oleh OJK dari pelapor. Meski demikian, pihak yang dapat

${ }^{26}$ Trisadini P. Usanti dan Fiska Silvia R.R, "Legal Protection of the Contracting Parties in The Peer to Peer Lending Based on Finacial Technology (P2P Lending Fintech) in Indonesia,", Advances in Social Science, Education and Humanities Research (ASSEHR), Vol.131, International Conference on Law, Governance and Globalization 2017 (ICLGG 2017), Atlantis Press, (2017), hlm. 291. 
mengajukan laporan atau sebagai pelapor hanya Bank Umum, BPR, BPRS, Lembaga Pembiayaan yang memberikan fasilitas penyediaan dana dan lembaga jasa keuangan lainnya yang memberikan fasilitas penyediaan dana, kecuali lembaga keuangan mikro. 27

Laporan Debitur tersebut wajib memuat informasi terkait debitur, fasilitas penyediaan dana, angunan, penjamin, pengurus dan pemilik, serta keuangan debitur. ${ }^{28}$ Akan tetapi, informasi laporan tersebut juga bersifat eksklusif dan terbatas. Eksklusif karena pihak yang dapat menjadi pelapor ialah penyelenggara P2PL dengan mengajukan permohonan dan mendapat persetujuan OJK dengan memenuhi persyaratan meliputi; memiliki infrastruktur yang memadai; memiliki data yang diperlukan dalam SLIK; dan menandatangani perjanjian keikutsertaan dalam pelaporan dan permintaan infromasi Debitur melalui SLIK.29 Selain itu pihak yang dapat meminta informasi debitur ialah Pelapor; debitur' LPIP; dan pihak lain. ${ }^{30}$

Maksud pihak lain dalam Pasal 20 ayat (1) POJK 18/2017 ialah pihak yang meminta informasi debitur dalam rangka pelaksanaan peraturan perundangundangan dan/atau berdasarkan nota kesepahaman dengan OJK. Misalnya pemerintah pusat, pemerintah daerah, lembaga negara, Bank Indonesia, Lembaga Penjamin Simpanan, Pusat Pelaporan dan Analisis Transaksi Keuangan, serta aparat penegak hukum dalam rangka pelaksanaan tugas dan wewenang berdasarkan peraturan perundang-undangan. ${ }^{31}$ Sehingga, dalam hal ini, informasi tersebut tidak terbuka bagi calon pemberi pinjaman (lender).

Sedangkan terbatas yakni, informasi yang diberikan hanya berisi identitas Debitur, pemilik dan pengurus bagi Debitur badan usaha, fasilitas penyediaan dana yang diterima Debitur, agunan, penjamin, kualitas fasilitas penyediaan dana, dan informasi lain berupa informasi keuangan Debitur. ${ }^{32}$ Pada Pasal 3 ayat (1) POJK 18/2017 mengatur bahwasannya ketentuan Lembaga Jasa Keuangan Lainnya yang menyediakan layanan pinjam-meminjam uang berbasis teknologi

\footnotetext{
27 Pasal 2 ayat (1) POJK No 18/POJK.03/2017

28 Pasal 4 ayat (2) POJK No 18/POJK.03/2017

${ }^{29}$ Pasal 3 ayat (1) POJK No 18/POJK.03/2017

30 Pasal 14 ayat (1) POJK No 18/POJK.03/2017

${ }^{31}$ Penjelasan Pasal 14 ayat (1) POJK No 18/POJK.03/2017

32 Pasal 14 ayat (2) POJK No 18/POJK.03/2017
} 
informasi dan lembaga keuangan mikro dapat menjadi Pelapor dengan mengajukan permohonan dan mendapat persetujuan OJK dengan memenuhi persyaratan:

1. memiliki infrastruktur yang memadai;

2. memiliki data yang diperlukan dalam SLIK; dan

3. menandatangani perjanjian keikutsertaan dalam pelaporan dan permintaan Informasi Debitur melalui SLIK.

Syarat-syarat di atas bersifat kumulatif sehingga harus dipenuhi semuanya, jika tidak dipenuhi salah satu maka tidak dapat menjadi Pelapor. Pasal 1 angka 8 mendefinisikan pelapor sebagai pihak yang melakukan pelaporan dan permintaan informasi debitur melalui sistem layanan informasi keuangan kepada OJK. 33

Pelapor SLIK dapat mengakses Website SLIK yang memilik fungsi untuk mengunggah berkas laporan, permintaan informasi debitur, pemantauan informasi debitur, pengelolaan pengguna, pemantauan aktivitas pengguna, dan koreksi data secara daring. Hal tersebut dapat dilakukan untuk mengetahui data terkait infomasi debitur yang mengajukan kredit pertama kali ataupun dalam masa peminjaman kredit oleh satu atau beberapa Lembaga Keuangan. ${ }^{34}$

Aplikasi SLIK terdiri dari 2 yaitu aplikasi SLIK Client dan aplikasi Web SLIK. Aplikasi SLIK Client yaitu aplikasi yang terpasang di perangkat komputer milik Pelapor yang memiliki fungsi untuk validasi data, enkripsi, kompresi, dan pembuatan file laporan siap kirim ke server SLIK. Fungsi lain dari aplikasi SLIK Client yaitu untuk mengirim laporan Debitur secara langsung ke server SLIK melalui File Transfer Protocol (FTP). ${ }^{35}$ Sedangkan aplikasi Web SLIK adalah sistem yang dapat digunakan melalui Web browser di internet atau eksranet OJK. Fungsi aplikasi Web SLIK tersebut yaitu untuk mengunggah berkas laporan Debitur sebagai alternatif pengiriman laporan, pemauntauan laporan, pemauntauan permintaan infomasi debitur, permintaan infromasi debitur, dan lain-lain.

${ }^{33}$ Inda Rahadiyan dan M. Hawin, Op. Cit., hlm. 295-296.

34 Ibid., hlm. 296-297.

35 Otoritas Jasa Keuangan, "Pedoman Penyusunan Laporan Debitur Melalui Sistem Layanan Informasi Keuangan Versi 6”, (2017), dikutip dari Inda Rahadiyan dan M. Hawin, Ibid., hlm. 297 
Permintaan informasi debitur hanya dapat ditampilkan menggunakan aplikasi $i D e b$ Viewer yang terpasang di komputer Pelapor. ${ }^{36}$

Meski kemudian OJK merilis regulasi terbaru berkaitan dengan mitigasi risiko atau manajemen risiko berupa POJK Nomor 4/POJK.05/2021 tentang Penerapan Manajemen Risiko Dalam Penggunaan Teknologi Informasi Oleh Lembaga Jasa Keuangan NonBank (LJKNB). Akan tetapi, mitigasi risiko pada peraturan tersebut berfokus pada teknis operasional teknologi yang digunakan oleh pihak penyelenggara LJKNB.

Sejauh ini, pengaturan mitigasi risiko dalam penyelenggaraan P2PL belum memberikan porsi maksimal pada aspek keterbukaan informasi. Padahal, keterbukaan informasi merupakan suatu alat yang dapat dipergunakan dalam meminimalisir atau memitigasi risiko, misalnya risiko pinjaman bermasalah atau kredit macet. Hal ini mengingat, penyampaian informasi yang secara jelas dan berkelanjutan terhadap kondisi peminjam, sejatinya membantu posisi peminjam itu sendiri. Adanya informasi-informasi yang jelas dan lugas, memudahkan pihak penyelenggara P2PL mengetahui kondisi finansial peminjam, sehingga dapat menyampaikan secara terbuka kepada pemberi pinjaman. Pemberi pinjaman dalam hal ini juga dapat memberikan kelonggaran waktu. Misalnya saja restrukturisasi pinjaman bermasalah.

\section{Penerapan Keterbukaan Informasi Sebagai Mitigasi Risiko P2PL di Amerika Serikat}

Prosper Marketplace, Inc. ("Prosper") dan Lending Club Corporation ("Lending Club") merupakan perusahaan platform P2PL ("Penyelenggara") yang pertama kali menginisiasi model bisnis P2PL di AS. ${ }^{37}$ P2PL AS dalam perkembangannya memiliki pertumbuhan cepat sebagaimana terlihat pada

\footnotetext{
${ }^{36}$ Inda Rahadiyan dan M. Hawin, Ibid.

${ }^{37}$ Prosper dan Lending Club dipertimbangkan sebagai "The Heartland of American Peer-to-Peer Lending". Sebabnya, pada awal pertumbuhan P2PL AS, mereka telah menyalurkan pinjaman lebih besar daripada pesaingnya, Kiva. Dalam perkembangannya, kedua Penyelenggara tersebut berhasil meraup 98\% pasar P2PL AS. Lihat: Andrew Verstein, "The Misregulation of Person-to-Person Lending”, UC Davis Law Review, Vol. 45, No. 2, November 21, 2011 dapat diakses SSRN: $\underline{\text { https://ssrn.com/abstract=1823763 or }}$ http://dx.doi.org/10.2139/ssrn.1823763 diakses pada 29 Oktober 2019, hlm. 452. Lihat juga: The Economist, "Peer-to-Peer Lending: Banking without bank"., https://wnw.economist.com/finance-and-economics/2014/02/28/bankingwithout-banks diakses 26 Oktober 2019.
} 
peningkatan pinjaman yang tersalurkan pada 2012, yakni 871.000.000 US Dollar dan terus meningkat menjadi 2.400.000.000 US Dollar pada 2013.38

Meskipun demikian, masa awal pertumbuhan P2PL AS memiliki permasalahan. Tingkat gagal bayar (default rate) dari para penggunanya mengalami peningkatan ${ }^{39}$ akibat belum matangnya formulasi pengaturan bagi eligibilitas peminjam. ${ }^{40}$ Mengingat permasalahan kredit sebagai katalis peristiwa resesi 2008, ${ }^{41}$ kaidah rule of law menjadi esensial dalam mengiringi pertumbuhan P2PL sembari menjaga stabilitas perekonomian AS. ${ }^{42}$

Sudah selayaknya apabila industri P2PL-industri yang memiliki lembaga penyaluran kredit kontemporer-menjadi agenda baru pembuat kebijakan. P2PL turut membawa risiko kredit ${ }^{43}$ (credit risk) dalam model bisnisnya. ${ }^{44}$ Apabila P2PL AS terus bertumbuh menjadi salah satu pilar stabilitas keuangan, ${ }^{45}$ maka kesehatan kredit industri P2PL AS harus diprioritaskan para pembuat kebijakan, baik dalam lingkup mikroprudensial maupun makroprudensial. ${ }^{46}$

38 Jumlah tersebut hanya ditarik dari jumlah pinjaman yang tersalurkan oleh Prosper dan Lending Club. Limitasi ini didasari dari besarnya cakupan pasar (98\%) P2PL AS oleh kedua Penyelenggara. Lihat: The Economist, Loc. Cit.

39 Westland, et. al., 2018. "Private Information, Credit Risk and Graph Structure in P2P Lending Networks", https://arxiv.org/pdf/1802.10000 diakses pada 20 November 2019, p. 2. Lihat juga: Matt Kennard dan Shannon Bond, Op. Cit.

${ }^{40}$ Ibid.

${ }^{41}$ Dimana, penyebab nyata - benar-benar pemicu sebenarnya - adalah lemahnya penyediaan kredit di pasar properti AS (di segmen subprima). Lihat: Karl Aiginger. "The Current Economic Crisis: Causes, Cures And Consequences", WIFO Working Papers, No. 341, 2009, hlm. 2.

42 Ada banyak bukti bahwa pembentukan negara hukum menarik investasi swasta, sejauh hal itu menciptakan iklim stabilitas dan prediktabilitas, di mana risiko bisnis dapat dinilai secara rasional, hak milik dilindungi, dan kewajiban kontrak dihormati. Penjelasan lebih lanjut, lihat: Ibrahim F.I. Shihata, "The Role of Law in Business Development", Fordham International Law Journal, Volume 20, Issue 5, Article 6, 1996, hlm. 1578.

${ }^{43}$ Dalam konteks P2PL, risiko kredit (credit risk) didefinisikan sebagai "Potential for financial losses resulting from the failure of a borrower to perform on an obligation" yakni Potensi kerugian finansial akibat kegagalan peminjam untuk memenuhi kewajibannya. Lihat: United States Government Accountability Office, GAO-11-613 Report to Congressional Committees: Person-To-Person Lending New Regulatory Challenges Could Emerge as the Industry Grows, (Juli 2011), hlm. 22, https://www.gao.gov/new.items/d11613.pdf., diakses pada 29 Oktober 2019.

${ }_{44}$ Pemberi pinjaman yang berpartisipasi dalam platform juga menghadapi berbagai risiko - terutama risiko kredit (kemungkinan peminjam dapat gagal membayar pinjaman mereka). Lihat: Ibid., hlm. 20.

45 Meskipun sampai saat ini P2PL belum terindikasi sebagai bagian indikator stabilitas sistem keuangan, secara garis model bisnis P2PL menyerupai model bisnis perbankan yang berperan sebagai penyalur kredit. Dalam konteks stabilitas keuangan, bank merupakan bagian dari "Measures of conditions of individual institutions", yakni mengukur kondisi masing-masing institusi. Sebagaimana yang dipaparkan oleh William R. Nelson dan Roberto Perli, "Bank dapat bertindak sebagai mekanisme transmisi krisis karena mereka dapat mengontrak kredit secara tajam dalam menanggapi permintaan deposan untuk pencairan dana secara cepat dan cepat. [...] praktik pemberian pinjaman yang agresif dan kontraksi pemberian pinjaman di bank disebut-sebut sebagai mekanisme transmisi masalah keuangan ke bisnis non keuangan dan rumah tangga". Lihat: Nelson, William R., and Roberto Perli. "Selected indicators of financial stability." Risk Measurement and Systemic Risk 4 (2007): 343-372., hlm. 355.

46 Peningkatan leverage pada saat perekonomian lesu dapat meletakkan risiko yang signifkan bagi peminjam (borrower). Lihat: Tim Dore dan Traci Mach (2019). "Marketplace Lending and Consumer Credit Outcomes: 
Praktik dan pengaturan P2PL di Amerika Serikat secara umum karakteristiknya terdapat pada sektor pinjaman kecil perorangan yang terkonsentrasi pada pasar, yakni 2 platform utama. Selain itu, sifat regulasi atas P2PL yakni ekstensive dan stringent. Sedangkan regulatory bodies yang bertindak yakni Securities and Exchange Commission yang mengatur investasi dan Protection Bureau and Federal Trade Commission yang mengawasi transaksi pinjaman. ${ }^{47}$ Berikut merupakan pengaturan P2PL dibawah SEC dan CFPB:

\section{a. Pengaturan oleh Securities and Exchange Commission United States Securities and Exchange Commission (SEC). ${ }^{48}$}

SEC adalah lembaga yang berwenang meski diperdebatkan, ${ }^{49}$ untuk mengatur Penyelenggara P2PL di AS50 di bawah Securities Act of 1933 ("Securities Act") ${ }^{51}$. Kondisi ini memberi opsi bagi Penyelenggara untuk mewajibkan pemberi pinjaman (lenders) mendaftarkan pinjaman yang ditawarkan (offerings) sebagai efek (securities) di SEC atau mendapatkan pengecualian terhadap Section 6 Securities Act. 52

Penyelenggara wajib memaparkan informasi lengkap terkait pinjaman dalam prospektus yang diperbaharui secara berkala yang dipublikasikan oleh SEC melalui sistem Electronic Data-Gathering, Analysis, and Retrieval (EDGAR). ${ }^{53}$

Evidence from Prosper," Finance and Economics Discussion Series 2019-022. Washington: Board of Governors of the Federal Reserve System, p. 32, https://doi.org/10.17016/FEDS.2019.022, , diakses 29 Oktober 2019.

47 Tabel 2: Comparative Practices and Regulatory Regimes of P2P, Naoko dan Bihong Huang, Op. Cit., hlm.7

48 U.S Securities and Exchange Commission adalah lembaga yang memiliki misi untuk melindungi investor, menjaga keadilan, ketertiban, dan pasar yang efisien serta memfasilitasi formasi permodalan. Lihat: U.S Securities and Exchange Commission, "What We Do: Introduction", https://www.sec.gov/Article/ whatwedo.html, diakses 25 Oktober 2019.

49 Akan tetapi, dari sisi kelembagaan, SEC diragukan untuk menjadi lembaga yang berwenang dalam mengatur P2PL. Lihat: Andrew Verstein, Op. Cit., p. 517. Di sisi lain, Paul Slattery menilai peran SEC akan tetap bertahan mengingat absennya tindakan kongres terhadap P2PL. Lihat juga: Paul. Slattery, "Square Pegs in a Round Hole: SEC Regulation of Online Peer-to-Peer Lending and The CFPB alternative," Yale J. on Reg., 30, 2013, hlm. 251.

${ }^{50}$ Lihat secara umum: Paul Slattery, Loc. Cit.

51 Securities Act of 1933 dirujuk sebagai “the truth in securities law". Peraturan tersebut memiliki 2 (dua) tujuan dasar: Pertama, mewajibkan investor untuk mendapatkan informasi finansial maupun informasi signifikan lainnya yang berkaitan dengan efek yang sedang ditawarkan untuk dijual kepada publik dan; Kedua, Melarang penipuan, malpresentasi, dan kecurangan dalam penjualan efek. Lihat: U.S Securities and Exchange Commission, "Securities Act of 1933", https://www.sec.gov/answers/about-lawsshtml.html diakses 25 Oktober 2019. Teks lengkap dapat diakses melalui: https://legcounsel.house.gov/Comps/Securities $\% 20$ Act $\% 200 f \% 201933$.pdf

52 5 6. [77] (a) Securities Act of 1933: "Any security may be registered with the Commission under the terms and conditions hereinafter provided [...] A registration statement shall be deemed effective only as to the securities specified therein as proposed to be offered".

53 "EDGAR adalah sistem Pengumpulan, Analisis, dan Pengambilan Data Elektronik yang digunakan di Komisi Sekuritas dan Bursa AS (SEC). EDGAR adalah sistem utama untuk pengiriman oleh perusahaan dan 
Melalui skema ini, pengajuan pinjaman P2PL menjadi lebih transparan bagi pemberi pinjaman dan pembeli di pasar sekunder yang mana para pihak terkait dapat mengakses informasi lengkap dari masing-masing pinjaman sebelum menentukan pinjaman yang akan didanai. ${ }^{54}$

Argumen kuat SEC atas kebijakan tersebut didasari dari praktik P2PL yang dilakukan oleh Prosper dan Lending Club. Berbeda dengan model bisnis P2PL secara umum, pemberi pinjaman (lender) Prosper dan Lending Club tidak secara langsung meminjamkan dana mereka melalui Penyelenggara. ${ }^{55}$ Sebagai gantinya, para peminjam (borrower) mendapatkan pinjaman dari WebBank, suatu bank yang telah diasuransikan oleh FDIC yang berbasis di Utah. ${ }^{56}$ Oleh karenanya, pinjaman yang disalurkan termasuk sebagai efek (securities) ${ }^{57}$ berdasarkan mekanisme Howey Test. Howey Test menentukan bahwa suatu transaksi mewakili kontrak investasi jika seseorang menginvestasikan uangnya di perusahaan umum dan diarahkan untuk mendapatkan keuntungan semata-mata dari upaya promotor atau pihak ketiga. .5

Securities and Exchange Commission (SEC) mewajibkan penyelenggara untuk memasukkan seluruh data material ke publik dengan batasan jenis data yang luas, sehingga platform wajib memasukkan semua informasi yang berkaitan dengan peminjam (borrower) pada web platform. ${ }^{59}$ Melalui informasi ini, maka para pemberi pinjaman (lender) dapat menganalisa profil dari peminjam terlebih dahulu sebelum

pihak lain yang diwajibkan oleh hukum untuk mengajukan informasi dengan SEC." Lihat: U.S Securities and Exchange Commission, "About EDGAR", https://www.sec.gov/edgar/aboutedgar.htm, diakses 25 Oktober 2019.

54 Jane J. Kim. "Peer-To-Peer Lender Relaunched", The Wall Street Journal https://www.wsi.com/articles/SB124088142201761953, , diakses pada 25 Oktober 2019.

${ }_{55}$ United States Government Accountability Office, Op. Cit., hlm. 10-14.

${ }^{56}$ Loc. Cit.

${ }^{57}$ Catatan yang ditawarkan oleh Prosper adalah sekuritas sesuai dengan Section 2(a)(1) of the Securities Act and under the Supreme Court's decisions in both SEC v. W. J. Howey Co., 328 U.S. 293 (1946), and Reves v. Ernst \& Young, Inc., 494 U.S. 56 (1990)." Lihat: SECURITIES AND EXCHANGE COMMISSION, SECURITIES ACT OF 1933 Release No. 8984: ORDER INSTITUTING CEASE-ANDDESIST PROCEEDINGS PURSUANT TO SECTION 8 A OF THE SECURITIES ACT OF 1933, MAKING FINDINGS, AND IMPOSING A CEASEAND-DESIST ORDER, p. 4. Teks lengkap dapat diakses melalui: https://www.sec.gov/litigation/ admin/2008/33-8984.pdf diakses pada 29 Oktober 2019.

58 Lihat: Investopedia, "Howey Test Definition", https://www.investopedia.com/terms/h/howeytest.asp, diakses 26 Oktober 2019. "Kontrak investasi Howey dengan mudah dapat dipenuhi oleh SEC. Prosper (dan Lending Club) berfungsi sebagai promotor untuk skema investasi umum dan investor mengandalkan keahlian penyelenggara P2PL untuk menemukan peluang dan beroperasi." Lihat: Warren, W.S., 2016. "The Frontiers of Peer-to-Peer Lending: Thinking About a New Regulatory Approach”, Duke L. \& Tech. Rev., 14, p.298, hlm. 303.

${ }^{59}$ Andrew Verstein, Op. Cit., hlm. 500. 
memutuskan untuk mengirim dana. Informasi ini tentunya dapat menguntungkan pemberi pinjaman dalam menganalisa potensi gagal bayar peminjam. ${ }^{60}$

Selain itu, dengan mekanisme kewajiban pendaftaran setiap pinjaman yang ditawarkan, SEC ${ }^{61}$ dapat memilah kualitas pinjaman yang sekiranya ideal untuk ditawarkan kepada masyarakat. ${ }^{62}$ Apabila dikaitkan dengan variabel credit grade, debt-to-income ratio, serta alur penggunaan kredit, maka mekanisme ini mampu menjaga tingkatan yang sehat bagi setiap pinjaman yang ditawarkan.63

Sebagaimana diatur pada Schedule A Securities Act of 1933, informasi yang wajib disampaikan pada tahapan pendaftaran efek (registration) meliputi: [...] (8) karakter umum bisnis yang sebenarnya ditransaksikan atau akan ditransaksikan oleh penerbit [...]; [...] (12) jumlah hutang didanai yang beredar dan akan dibuat oleh sekuritas yang akan ditawarkan, dengan uraian singkat tentang tanggal, jatuh tempo, dan karakter hutang tersebut, tingkat bunga, karakter ketentuan amortisasi, dan keamanan, jika ada, untuk itu. Jika substitusi keamanan apapun diperbolehkan, pernyataan ringkasan dari kondisi di mana substitusi tersebut diperbolehkan. Jika substitusi diperbolehkan tanpa pemberitahuan, pernyataan spesifik tentang efek tersebut [...]; [...] (13) tujuan spesifik secara rinci dan perkiraan jumlah yang akan dikhususkan untuk tujuan tersebut, sejauh dapat ditentukan, di mana jaminan yang akan ditawarkan adalah untuk memasok dana, dan jika dana akan dikumpulkan dalam bagian dari sumber lain yang jumlah dan sumbernya harus dicantumkan [...];"64

Namun, mekanisme SEC dinilai masih belum ideal bagi investor ritel yang mencari pinjaman modal tambahan dari Prosper dan Lending Club. Pengaturan di masa depan harus meninjau optimalisasi risiko manajemen melalui penyesuaian pertanggungjawaban penyelenggara bagi kredit macet. 65

${ }^{60}$ Lihat: Riza Emekter, Yanbin Tu, Benjamas Jirasakuldech \& Min Lu, Op. Cit., hlm. 61.

${ }^{61}$ Securities Exchange Commission, Securities Act 1933 Release No. 8984, Loc.cit.

${ }^{62} \mathrm{Hal}$ ini turut sejalan dengan misi SEC untuk melindungi kepentingan investor, memelihara pasar yang adil, tertib dan efisien. Lihat: United States Securities and Exchange Commission, "About the SEC", https://www.sec.gov/about.shtml, diakses pada 26 Oktober 2019.

${ }^{63}$ Teks lengkap dapat diakses melalui: https://www.sec.gov/litigation/admin/2008/33-8984.pdf. diakses pada 26 Oktober 2019.

${ }^{64}$ Teks lengkap dapat diakses melalui: https://www.sec.gov/litigation/admin/2008/33-8984.pdf. diakses pada 26 Oktober 2019.

65 Warren, W.S., “The Frontiers of Peer-to-Peer Lending: Thinking About a New Regulatory Approach", Duke L. \& Tech. Rev., 14, (2016), hlm. 298, hlm. 303, hlm. 313-314. 


\section{b. Pengaturan oleh Consumer Financial Protection Bureau}

Bagi peminjam (borrowers), pada awalnya setiap transaksi P2PL diatur oleh usury law ${ }^{66}$ negara-negara bagian (states) AS. Namun, pasca diundangkannya Dodd-Frank Wall Street Reform and Consumer Protection Act67 ("Dodd-Frank") pada tahun 2010, kewenangan pengaturan bagi peminjam beralih ke Consumer Financial Protection Bureau (CFPB). 68 Perpindahan ini mengacu pada 2 alasan: Pertama, keuntungan dari adanya lembaga tunggal yang berfokus pada P2PL;69 Kedua, lahirnya lembaga yang berfokus pada kredit konsumen P2PL. ${ }^{70}$

Pada awalnya gagasan pendirian CFPB ialah untuk menjadi lembaga tunggal yang mengatur P2PL. ${ }^{71}$ CFPB turut diberi mandat untuk menjangkau penyelenggara yang berpotensi berisiko bagi konsumen dalam transaksi keuangan di seluruh yurisdiksi negara bagian AS.72 Namun, pihak pemerintah AS memilih untuk bersikap dengan pendekatan wait-and-see bagi pengaturan P2PL. ${ }^{73}$ Oleh karenanya, sampai saat ini Penyelenggara P2PL masih diwajibkan untuk mendaftarkan ke SEC ataupun mendapatkan pengecualian (exemption) atas pinjaman yang disalurkan. ${ }^{74}$

${ }^{66}$ Usury law adalah hukum yang mengatur secara spesifik suku bunga maksimum yang dapat dibuat dari pinjaman. Setiap negara bagian AS memiliki usury law yang berbeda-beda. Lihat secara umum: Docutech Corporation, "Maximum Interest Rate Matrix", https://www.docutech.com/wpcontent/uploads/2013/05/Maximum-Interest-Rate-Matrix-2013.pdf, accessed 25 Oktober 2019.

${ }^{67}$ Dodd-Frank Wall Street Reform and Consumer Protection Act adalah undang-undang federal Amerika Serikat yang diundangkan pada 21 Juli 2010. Peraturan ini mengubah secara keseluruhan peraturan sektor keuangan pasca krisis 2008 serta memberi dampak bagi seluruh regulator dan industri yang berkaitan dengan sektor jasa keuangan AS. Lihat secara umum: United States Democratic Policy Committee, "Brief Summary of The DODD-FRANK Wall Street Reform and Consumer Protection Act", https://www.dpc.senate.gov/pdf/wall street reform summary.pdf, accessed 25 Oktober 2019. Teks lengkap dapat diakses melalui: https://www.govinfo.gov/content/pkg/PLAW-111publ203/pdf/PLAW-111publ203.pdf

68 CFPB adalah lembaga yang mengatur penawaran dan ketentuan produk maupun jasa keuangan konsumen di bawah peraturan federal tentang finansial konsumen dan bertugas untuk mengedukasi serta memberdayakan konsumen untuk membuat keputusan finansial yang lebih matang. Lihat: Consumer Financial Protection Bureau, “About Us", https://www.consumerfinance.gov/about-us/, accessed 25 Oktober 2019.

${ }^{69}$ Warren, W.S., Op. Cit., hlm. 304.

${ }^{70}$ United States Government Accountability Office, Op. Cit. hlm. 36-37.

71 Warren, W.S., Op. Cit., hlm. 304-305.

${ }^{72} \mathrm{Hal}$ ini dinilai cocok bagi bentuk negara federasi seperti AS. Daripada menundukkan borrower P2PL yang sudah ada dan parapendatang baru terhadap regulasi oleh berbagai agen negara bagian dan federal, borrower P2PL dapat memperoleh keuntungan dari kepastian yang datang melalui interaksi pada satu regulator. Para pendukung CFPB sebagai model regulator tunggal dengan mandat/kewenangan yang luas, yang mengawasi P2PL, menunjukkan bahwa regulator dapat jauh lebih responsif terhadap inovasi dan model baru P2PL" Lihat: P. Slattery, Op. Cit., hlm. 264.

${ }^{73}$ United States Government Accountability Office, Op. Cit. hlm. 56-57.

${ }^{74}$ W.S Warren., Op. Cit., hlm. 305 
Meskipun sampai saat ini perdebatan kewenangan lembaga yang dapat mengatur P2PL AS masih berdengung, pada 7 Maret 2016 CFPB menyatakan mampu untuk menerima aduan konsumen pinjaman dari P2PL. ${ }^{75}$ Secara garis besar, CFPB memberi panduan bagi peminjam sebelum mengajukan pinjaman, yakni: 1) meninjau pendapatan dan pengeluaran;76 2) meninjau laporan kredit;77 dan 3) mempertimbangkan tingkat suku bunga yang ditawarkan oleh para penyelenggara. ${ }^{78}$

Berkenaan dengan variabel risiko kredit, peminjam mampu lebih hati-hati dalam mengambil keputusan kredit P2PL. Dengan demikian, panduan CFBP mampu memitigasi poin credit rate, debt-to-income ratio, dan alur penggunaan kredit.

Tabel 1. Perbandingan Pengaturan Umum P2PL di Amerika Serikat

\begin{tabular}{|c|c|c|}
\hline Keterangan & SEC & CFBP \\
\hline Payung hukum & Securities Act & Dodd-Frank \\
\hline Subyek & Lender dan Penyelenggara & Borrower \\
\hline \multirow[t]{5}{*}{ Poin Pengaturan } & $\begin{array}{l}\text { Lender wajib mendaftarkan } \\
\text { pinjaman sebagai efek }\end{array}$ & $\begin{array}{l}\text { Borrower } \\
\text { pendapatan }\end{array}$ \\
\hline & Penyelenggara & pengeluaran, \\
\hline & memberi & lapoan \\
\hline & dalam prospektus secara & pertimbangan suku bunga \\
\hline & berkala melalui EDGAR & \\
\hline
\end{tabular}

Sumber: Pengolahan Penulis, 2019

\section{Penutup}

Berdasar pada hasil analisis di atas, maka penelitian ini menyimpulkan: pertama, meski POJK telah memuat mengenai kewajiban keterbukaan informasi, akan tetapi aturan tersebut dirasa kurang memadai mengingat informasi yang disampaikan bersifat eksklusif dan terbatas. Hal ini mengingat informasi tersebut

75 Consumer Financial Protection Bureau, "CFPB Now Accepting Complaints on Consumer Loans from Online Marketplace Lender", https://www.consumerfinance.gov/about-us/newsroom/cfpb-now-accepting-complaintson-consumer-loans-from-online-marketplace-lender/, diakses pada 28 Oktober 2019.

${ }^{76}$ Ibid.

77 "Check credit reports: Konsumen harus memeriksa laporan kredit mereka untuk memastikan tidak ada kesalahan yang dapat menghalangi mereka untuk mendapatkan kredit atau mendapatkan persyaratan pinjaman terbaik yang tersedia. Konsumen harus yakin bahwa informasi dalam laporan tersebut akurat dan mutakhir" Lihat: Consumer Financial Protection Bureau, "CFPB Now Accepting Complaints on Consumer Loans from Online Marketplace Lender, Loc. Cit.

78 "Shop around: Konsumen yang mempertimbangkan tingkat suku bunga yang ditawarkan oleh banyak pemberi pinjaman atau broker mungkin melihat perbedaan besar dalam tingkat tersebut. Konsumen harus membandingkan biaya dan persyaratan pinjaman untuk menemukan kesepakatan yang terbaik bagi mereka" Lihat: Consumer Financial Protection Bureau, "CFPB Now Accepting Complaints on Consumer Loans from Online Marketplace Lender, Loc. Cit. 
tidak dapat diakses oleh calon pemberi pinjaman dan hanya dapat diakses oleh pihak-pihak tertentu saja. Selain itu, informasi terkait kondisi peminjam yang berkelanjutan saat proses pinjam-meminjam berlangsung juga tidak tersedia, sehingga dapat menimbulkan risiko pinjaman macet. Padahal, ketersediaan kondisi peminjam yang mengalami kesulitan pembayaran, dapat memberikan alternatif bagi pemberi pinjaman untuk memberikan kelonggaran waktu. Misalnya saja restrukturisasi pinjaman bermasalah. Sehingga dalam hal ini kedua pihak sama-sama dalam 'kondisi rela' bertransaksi di P2PL.

Kedua, penerapan keterbukaan informasi pada P2PL di Amerika Serikat melalui Securities and Exchange Commission (SEC) yang mewajibkan penyelenggara untuk memasukkan seluruh data material ke publik secara berkala, sehingga platform wajib memasukkan semua informasi yang berkaitan dengan peminjam (borrower) pada web platform. Melalui informasi ini, maka para pemberi pinjaman (lender) dapat menganalisa profil dari peminjam terlebih dahulu sebelum memutuskan untuk mengirim dana.

Selain itu, melalui Consumer Financial Protection Bureau (CFPB), CFPB memberi panduan bagi peminjam sebelum mengajukan pinjaman, yakni: 1) meninjau pendapatan dan pengeluaran; 2) meninjau laporan kredit; dan 3) mempertimbangkan tingkat suku bunga yang ditawarkan oleh para penyelenggara. Sehingga, peminjam mampu lebih hati-hati dalam mengambil keputusan kredit P2PL.

Pengaturan keterbukaan informasi dalam penyelenggaraan P2PL di Amerika Serikat dapat menjadi satu substansi pengaturan yang penting untuk dipertimbangkan oleh Otoritas Jasa Keuangan dalam kedudukannya sebagai regulator dan pengawas P2PL di Indonesia. Usulan demikian dapat dipahami mengingat keterbukaan adalah kunci paling mendasar bagi mitigasi risiko pada mekanisme P2PL dengan segala kemudahan transaksi yang ditawarkan.

\section{Daftar Pustaka}

\section{Buku}

Anshari, Muhammad, Mohammad Nabil Almunawar dan Masairol Masri, An Overview of Financial Technology in Indonesia, Chapter 12, An Overview of Financial Technology in Indonesia, IGI Global, 2020. 
Christhi, Susanne and Janos Barberis, The Fintech Book: The Financial Technology Handbook for Investors, Enterpreuners and Visionaries, John Wiley \& Sons Ltd, West Sussex, 2016.

Cummins, Mark, et.al, Addressing Information Asymmetries in Online Peer-to-Peer Lending, dalam Theo Lynn, et.al, Disrupting Finance: Fintech and Strategy in 21 ${ }^{\text {st }}$ Century, Springer Nature, Switzerland, 2019.

D.W., Arner, Barberis, J., and Buckley, R.P, The Evolution of FinTech: A New PostCrises Paradigm, University of Hongkong, 2015.

Freedman, Roy S. Introduction to Financial Technology, Complete Technology Guides for Financial Services, Elsevier, California, 2006.

Marzuki, Peter Mahmud, Penelitian Hukum, Kencana Prenada Media Group, Jakarta, 2013.

Muhammad, Abdulkadir, Hukum dan Penelitian Hukum, Cetakan Kesatu, Bandung, PT Citra Aditya Bakti, 2004.

Rubini, Agustin, Fintech in A Flash: Financial Technology Made Easy, Simtac Ltd, London, 2017.

\section{Jurnal}

A, Eugenia Omarini, "Peer-to-peer Lending: Business Model Analysis and the Platform Dilemma," International Journal of Finance, Economics and Trade (IJFET), 2(3), 2018

Diyanti, Anin dan Endang Tri Wiyarti, "Analisis Pengaruh Faktor Internal dan Eksternal Terhadap Terjadinya Non Performing Loan (Studi Kasus pada Bank Umum Konvensional yang Menyediakan Layanan Kredit Pemilikan Rumah Periode 2008-2011)", Diponegoro Journal of Management, Vol.1, No.2, 2012.

Dwihandayani, Deasy, "Analisis Kinerja Non Performing Loan (NPL) Perbankan di Indonesia dan Faktor-Faktor yang Mempengaruhi NPL", Jurnal Ekonomi Bisnis, Vol.22, No.3, 2017.

Emekter, Riza, et.al, “Evaluating credit risk and loan performance in online Peerto-Peer (P2P) lending", Applied Economics, 47:1, 2015.

Manan, Yulianti M. "Sistem Integrasi Proteksi \& Manajemen Resiko Platform Fintech peer to Peer (P2P) Lending dan Payment Gateway untuk Meningkatkan Akselerasi Pertumbuhan UMKM 3.0," Journal of Islamic Economic, Finance, and Banking, Vol.2, No.1, 2019.

Rahadiyan, Inda dan M. Hawin, "Pengaturan dan Penerapan Mitigasi Risiko Dalam Penyelenggaraan Peer To Peer Lending Guna Mencegah Pinjaman Bermasalah", Jurnal Hukum, IUS QUIA IUSTUM, No.2, Vol.27, Mei 2020.

Shihata, Ibrahim F.I "The Role of Law in Business Development", Fordham International Law Journal, Volume 20, Issue 5, Article 6, 1996. 
Slattery, P. “Square Pegs in a Round Hole: SEC Regulation of Online Peer-to-Peer Lending and The CFPB Alternative", Yale J. on Reg, 30, 2013.

Usanti, Trisadini P. dan Fiska Silvia R.R, "Legal Protection of the Contracting Parties in The Peer to Peer Lending Based on Finacial Technology (P2P Lending Fintech) in Indonesia,", Advances in Social Science, Education and Humanities Research (ASSEHR), Vol.131, International Conference on Law, Governance and Globalization 2017 (ICLGG 2017), Atlantis Press, (2017).

Uyen, Tran Dinh and Hoang $\mathrm{Ha}$, “The Sharing Economy and Collaborative Finance: the Case of P2P Lending in Vietnam", Jurnal Ekonomi Bisnis, Vol. 22, No. 2, 2017.

Verstein, Andrew "The Misregulation of Person-to-Person Lending", UC Davis Law Review, Vol. 45, No. 2, November 21, 2011.

Warren, W.S., "The Frontiers of Peer-to-Peer Lending: Thinking About a New Regulatory Approach", Duke L. E Tech. Rev., 14, 2016.

\section{Makalah}

Aiginger, Karl "The current economic crisis: causes, cures and consequences", No. 341. WIFO Working Papers, 2009.

Napitupulu, Sarwin Kiko, et.al. "Kajian Perlindungan Konsumen Sektor Jasa Keuangan: Perlindungan Konsumen Pada Fintech", Departemen Perlindungan Konsumen Otoritas Jasa Keuangan Republik Indonesia, 2017.

Nemoto, Naoko and Bihong Huang, "Optimal Regulation of P2P Lending for Small and Medium-Sized Eterprises", No.912, ADBI Working Paper Series, January 2019

Nelson, William R., and Roberto Perli. "Selected Indicators of Financial Stability." Risk Measurement and Systemic Risk 4. 2007.

Passagi, Hendrikus "Fintech Lending Indonesia Pendanaan Gotong Royong Online", Materi Seminar Nasional "Implementasi dan Tantangan Fintech Lending di Indonesia", Kerjasama antara Business Law Community Fakultas Hukum UGM dengan Otoritas Jasa Keuangan Republik Indonesia, Yogyakarta 22 September 2018.

\section{Peraturan Perundang-Undangan}

Peraturan Bank Indonesia Nomor 19/12/PBI/2017 tentang Penyelenggaraan Teknologi Finansial

Peraturan Otoritas Jasa Keuangan Nomor 77/POJK.01/2016 tentang Pinjam Meminjam Uang Berbasis Teknologi Informasi

Peraturan Otoritas Jasa Keuangan Nomor 13/POJK.02/2018 Tentang Inovasi Keuangan Digital di Sektor Jasa Keuangan.

Securities Exchange Act of the United States of America year of 1933 


\section{Internet}

Benjamin Kafer, "Peer to Peer Lending: A Financial Stability Risk Perspective", dapat diakses pada http://www.uni-marburg.de/fb02/ makroforschung/magkspapers diakses 16 Juli 2019.

CNBCIndonesia, "Ini dia empat jenis fintech di Indonesia", https:/ / www.cnbcindonesia.com/tech/20180110145800-37-1126/ini-diaempat-jenis-fintech-di-indonesia diakses 28 Oktober 2019

Consumer Financial Protection Bureau, "CFPB Now Accepting Complaints on Consumer Loans from Online Marketplace Lender", https://www.consumerfinance.gov/about-us/newsroom/cfpb-nowaccepting-complaints-on-consumer-loans-from-online-marketplacelender /, accessed 28 Oktober 2019.

Consumer Financial Protection Bureau, "About Us", https:/ /www.consumerfinance .gov/about-us/, accessed 25 Oktober 2019.

Docutech Corporation, "Maximum Interest Rate Matrix", https://www.docutech .com/wp-content/uploads/2013/05/Maximum-Interest-Rate-Matrix2013.pdf, accessed 25 Oktober 2019.

Investopedia, "Howey Test Definition", https://www.investopedia. com/terms/h/howey-test.asp, diakses 26 Oktober 2019.

Investopedia, "Details of Payment Dependent Notes", https: / /www.investopedia .com $/$ terms $/ \mathrm{m} /$ member-payment-dependent-note.asp, accessed 27 Oktober 2019.

Jane J. Kim. "Peer-To-Peer Lender Relaunched", The Wall Street Journal https://www.wsj.com/articles/SB124088142201761953, Accessed 25 Oktober 2019.

Kevin David, et.all, Catching-Up with Indonesia's Fintech Industry, Working Paper, Australian Centre for Financial Studies Monash Univesity, May 2017, https: / / australiancentre.com.au/wp-content/uploads/2017/05/2_

Catching-Up-with-Indonesias-Fintech-Industry.pdf diakses 29 Oktober 2018

Kieran Garvey. Et.all., Laporan Industri Keuangan Alternatif Asia-Pasifik Ke-2: Meningkatkan Pertumbuhan, The Australian Centre for Financial Studies Monash University bekerja sama dengan Cambridge Centre for Alternative Finance dan Tsinghua University, https://australiancentre. com.au/wp-content/uploads/2017/09/APAC_BH_e.pdf accessed 25 Nopember 2018

Matt Kennard dan Shannon Bond, "Interest soars in US peer-to-peer lending", https:/ / www.ft.com/content/2345e94a-0bb1-11e1-9a6100144feabdc0\#ixzz21aKdQtwL diakses 24 Oktober 2019. 
The Economist, "Peer-to-Peer Lending: Banking without bank"., https://www.economist.com/finance-and-economics/2014/02/28/bankingwithout-banks diakses 26 Oktober 2019.

Tim Dore dan Traci Mach (2019). "Marketplace Lending and Consumer Credit Outcomes: Evidence from Prosper," Finance and Economics Discussion Series 2019-022. Washington: Board of Governors of the Federal Reserve System, https://doi.org/10.17016/FEDS.2019.022 accessed 29 Oktober 2019

United States Government Accountability Office, GAO-11-613 Report to Congressional Committees: PERSON-TO-PERSON LENDING New Regulatory Challenges Could Emerge as the Industry Grows, https://www.gao.gov/new.items/d11613.pdf. accessed 29 Oktober 2019

United States Democratic Policy Committee, "Brief Summary of The DODD-FRANK Wall Street Reform and Consumer Protection Act", https://www.dpc.senate.gov/pdf/wall_street_reform_summary.pdf. 25 Oktober 2019

U.S Securities and Exchange Commission, "What We Do: Introduction", https://www.sec.gov/Article/whatwedo.html, diakses 25 Oktober 2019.

U.S Securities and Exchange Commission, "About EDGAR", https://www.sec.gov/edgar/aboutedgar.htm, diakses 25 Oktober 2019.

U.S Securities and Exchange Commission, "Securities Act of 1933", https://www.sec.gov/answers/about-lawsshtml.html diakses 25 Oktober 2019.

Westland, et. al., 2018. "Private Information, Credit Risk and Graph Structure in P2P Lending Networks", https://arxiv.org/pdf/1802.10000 diakses pada 20 November 2019. 